\title{
Identitas Personal: Refigurasi Pembantu Rumah Tangga Tenaga Kerja Wanita di Hong Kong dalam Teks Diary Buruh Migran Karya Arsya Kirana
}

\author{
Jamila Wijayanti \\ Program Studi Pendidikan Bahasa dan Sastra Indonesia Fakultas Ilmu Budaya \\ Universitas Brawijaya Malang. Jalan Veteran Malang 65145 \\ E-mail: jamilawijayanti@ub.ac.id No. HP 081231667877
}

\begin{abstract}
Abstrak: Penelitian ini bertujuan untuk merepresentasikan identitas personal tokoh pembantu rumah tangga tenaga kerja wanita di Hong Kong (PRT TKW HK) yang tercermin dalam teks Diary Buruh Migran karya Arsya Kirana. Fokus penelitian ini secara khusus membahas refigurasi PRT TKW HK dengan mendeskripsikan tokoh buruh migran dalam teks Diary Buruh Migran. Penelitian ini menggunakan pendekatan kualitatif dengan metode deskriptif. Analisis dilakukan dengan menggunakan sosiologi sastra. Teori Paul Recouer tentang naratif dan personal identitas digunakan oleh peneliti sebagai landasan teori. Sebagaimana pendekatan sosiologi sastra yang digunakan, maka tidak menutup kemungkinan peneliti menggunakan teori lain seperti teori sosial dan budaya untuk pengayaan. Hasil penelitian menujukan bahwa refigurasi tokoh buruh migran memiliki peran besar dalam membentuk identitas personal tokoh PRT TKW HK.
\end{abstract}

Kata kunci: refigurasi, tokoh, buruh migran, identitas personal

Tokoh sebagai manusia yang ditampilkan dalam teks Diary Buruh Migran merupakan sosok yang memiliki identitas. Identitas tersebut perlu diinterpretasikan supaya unsur-unsur yang membentuk tokoh dapat dipresentasikan kembali. Identitas manusia menurut Recoeur tidak serta-merta ada begitu saja melekat pada dirinya. Tetapi melalui beberapa proses yang dilewati selama perjalanan hidupnya. Narasi berperan besar dalam pembentukan identitas personal manusia. Hal ini sesuai menurut pandangan Recoeur dalam Venema (1996) yang menyatakan bahwa secara khusus narasi memiliki kapasitas untuk membawa cahaya proses temporal pembentukan identitas. Narasi, sebagaimana wacana kreatif seharusnya membawa pengalaman bahasa, tetapi pengalaman tertentu yang sesuai dengan bentuk narasi adalah 
dunia temporalis manusia dan tindakan, yaitu dunia yang subjek agen untuk mengubah dan mengalami perubahan oleh agen dalam pencarian identitas mereka.

Berbagai peristiwa beragam yang dialami oleh manusia baik secara pribadi maupun kolektif akan membentuk sebuah narasi tentang siapa dirinya. Untuk mencari identitas diri, manusia harus menerima pengalamannya di masa lalu sebagai sebuah tahapan yang harus dilewati menuju apa yang ingin dicapainya di masa sekarang dan di masa yang akan datang. Melalui proses dan pengalaman itulah identitas personal tokoh dapat terbentuk. Tahapantahapan yang dilalui manusia sebagai proses yang menarasikan identitasnya tersebut oleh Recoeur dalam Vemena (1996) dibagi dalam tiga hal yakni prefigurasi, konfigurasi, dan refigurasi.

Tahapan-tahapan narasi dalam diri tokoh ini merupakan proses yang berkelanjutan dalam satu kesatuan yang terus menerus berputar. Pada penelitian sebelumnya dalam tahap prefigurasi disimpulkan bahwa buruh migran memiliki latar belakang keluarga single parent/orang tua tunggal. Buruh migran memiliki latar belakang agama Islam. Secara sosial ekonomi, buruh migran berasal dari keluarga miskin pedesaan. Rata-rata buruh migran memiliki latar belakang pendidikan rendah. Latar belakang buruh migran tersebut selanjutnya menumbuhkan cita-cita untuk mengubah kehidupan menjadi lebih baik. Buruh migran memiliki pandangan bahwa materilah yang dapat mengangkat status sosial di masyarakat tanah kelahirannya.

Konfiguratif sebagai ruang pengharapan, dunia batin tokoh buruh migran dalam menghadapi permasalahan hidupnya memiliki perasaan yang bermacam-macam. Tokoh buruh migran merasa gelisah, kemarahan, dan tetidak adilan selama menjalani kidipan dari pramigran hingga migran. Fenomena culture shock sempat dialami dengan adanya adaptasi dan benturan budaya. Beberapa terjerumus ke pada pergaulan bebas, lesbian, narkoba dan mangalami pelecehan baik seksual maupun psikologis oleh beberapa pihak.

Selanjutnya, penelitian ini lebih menekankan pada refigurasi PRT TKW HK dalam teks Diary Buruh Migran karya Arsya Kirana. Refigurasi dipilih karena merupakan pemantaban identitas personal tokoh yang diinterpretasi setelah melampau proses prefigurasi dan konfigurasi. Pemantaban identitas tokoh dilakukan pada refigurasi, yakni dengan menginterpretasi kembali figur tokoh. Identitas baru tokoh akan ditemukan setelah melewati proses tersebut.

Refigurasi berada dalam wilayah pemahaman akhir terhadap makna hidup tokoh yang telah dilewati semenjak alur prefiguratif dalam ruang pengalaman dan konfiguratif dalam 
ruang pengharapan. Pemaknaan tersebut bergantung pada setiap peristiwa hidup yang dipahami sebagai fregmen yang membawa dirinya pada sebuah narasi besar tentang dirinya. Tokoh dalam hal ini melihat dunia yang dihadapinya berdasarkan orientasi sosial dan kultural yang dipahaminya.

Tokoh sebagai agen melewati berbagai peristiwa dalam alur cerita. Melalui peristiwaperistiwa yang membentuk sebuah narasi, pada akhirnya tokoh memiliki pemaknaan yang mendalam tentang dirinya, dimana dia berpiijak, dan bagaimana dia mengambil peran dalam kehidupan. Keyakinan tokoh akan dirinya merupakan bentuk eksistensinya dalam kehidupan. Hal tersebut lah yang mencerminkan refiguratif. Sebagaimana pendapat Recoeur dalam Vemena (1996)

Dunia teks pada akhirnya adalah dunia yang menginstruksikan subjek secara etis terhadap tindakan intersubjektif yang membutuhkan stabilitas tujuan dan kesetiaan terhadap orang lain melalui "keputusan dimana seseorang mengatakan: Di sini aku berdiri". Teks "provokasi untuk menjadi dan akan bertindak secara berbeda" memerlukan tindakan etis, dan "sehingga identitas naratif tidak sama dengan kebenaran keteguhan diri kecuali melalui saat yang menentukan ini, yang membuat tanggung jawab etis menjadi faktor tertinggi dari keteguhan diri".

Hal ini berarti bahwa ketika tokoh telah menentukan jati dirinya-eksistensi dirinya, dimana dia berada, dan peran apa yang diambilnya dalam hidup dan kehidupan — maka tokoh akan berkomitmen pada pendiriannya. Komitmen tersebut membuat tokoh setia pada apa yang menjadi dasar atau filosofi hidupnya. Hal tersebut yang menuntun tokoh untuk bertindak secara berbeda berdasarkan pemahaman baru akan jati dirinya. Maka dari itu, besar kemungkinan komitmen kesetiaan atas jati dirinya akan bertentangan dengan lingkungan sosialnya. Akan tetapi, disitulah identitas tokoh yang telah ditemukannya teruji.

Refigurasi sebagai identitas personal tokoh yang diuntai dalam narasi cerita mampu mempersuasi pembaca untuk melakukan tindakan serupa. Identitas tokoh yang tercermin dalam sikap hidupnya tersebut akan dimaknai oleh pembaca berdasarkan pengalaman pribadinya. Untuk itu, refigurasi merupakan penafsiran terhadap tokoh yang mampu memprovokasi pembaca untuk sebuah tidakan lain sebagai reaksi dari pembacaan. Hal ini sebagaimana yang dimaksud oleh Recoeur dalam Vemena (1996) bahwa "refigurasi harus membebaskan diri, sekali dan untuk semua, dari kosakata referensi". Jika kedua kisah sejarah dan fiksi dapat dipahami melalui "referensi produktif," maka kedua bentuk narasi akan memiliki kapasitas untuk menghasilkan inovasi dalam dunia pembaca. Membaca merupakan kegiatan sintetis yang membangun analogi antara dunia teks dan pembaca. 


\section{METODE}

Penelitian ini dilaksanakan dengan pendekatan kualitatif dengan metode penelitian deskriptif. Penelitian ini mendeskripsikan refigurasi PRT TKW HK dalam teks Diary Buruh Migran karya Arsya Kirana. Penelitian ini tergolong penelitian kepustakaan, yakni penelitian ini dilakukan berdasarkan dokumen karya tertulis dengan tujuan mengumpulkan data dan informasi dengan bantuan macam-macam material yang terdapat di ruang perpustakaan. Pendekatan analisis yang digunakan adalah sosiologi sastra, hal ini sesuai dengan fokus kajian penelitian ini yang dimaksudkan untuk mendeskripsikan refigurasi PRT TKW HK. Teori Paul Recouer tentang narasi dan personal identitas digunakan sebagai landasan teori dalam penelitian ini. Peneliti tidak menutup kemungkinan untuk menggunakan teori lain seperti teori sosial dan budaya untuk pengayaan, sebagaimana teori sosiologi sastra ini digunakan.

Sumber data dalam penelitian ini berupa catatan harian yang ditulis oleh Arsya Kirana dengan judul Diary Buruh Migran. Data penelitian berupa teks yang terdapat dalam Diary Buruh Migran berkaitan dengan kehidupan buruh migran. Data terpilih berdasarkan refigurasi PRT TKW HK. Instrumen penelitian yang digunakan dalam penelitian ini adalah alat bantu yang berupa matrik penjaring data. Peneliti sebagai instrumen utama yeng bertindak sebagai perencana, pelaksana pengumpul data, analis, penafsir data, dan akhirnya sebagai pelapor hasil penelitian (Moleong, 2010:168).

Adapun pengumpulan data penelitian ini mencakup lima langkah. Pertama, membaca catatan harian Diary Buruh Migran karya Arsya Kirana sebagai sumber data secara seksama dan berulang-ulang untuk memperoleh pemahamanan dan penghayatan sehingga diperoleh gambaran umum mengenai isi cerita. Kedua, identifikasi data dimulai dengan menjaring data yang berkaitan konsep penelitian yang ada dalam catatan harian Diary Buruh Migran karya Arsya Kirana. Kegiatan ini dilakukan dengan menandai teks yang berhubungan dengan fokus masalah dan teridentifikasi sebagai data. Ketiga, mengambil unit-unit kalimat, paragraf, atau dialog yang menunjukkan refigurasi tokoh buruh migran sesuai fokus penelitian. Keempat, mengklasifikasikan data berdasarkan permasalahan sesuai fokus penelitian. Kelima, memberi kode unit-unit data untuk mempermudah pengorganisasian data.

Analisis data yang digunakan dalam penelitian ini mencakup lima langkah. Pertama reduksi, yakni pemilihan data yang prioritas dengan yang tidak. Data yang prioritas dikumpulkan untuk diorganisasi, sedangkan data yang kurang prioritas disimpan untuk 
sewaktu-waktu dapat diambil kembali apabila diperlukan. Kedua, yaitu menafsirkan data dengan mengaitkan antara teks dengan kontek, memaknai secara simantis dan simbolis. Keempat deskripsi, mendeskripsikan hasil interpretasi dengan mengaitkan pada landasan teori. Kelima penarikan kesimpulan, yakni kegiatan penyimpulan hasil penelitian yang telah dilakukan.

\section{HASIL DAN PEMBAHASAN}

Kajian dalam artikel ini lebih menekankan pada refigurasi tokoh buruh migran yaitu gambaran atau kondisi yang menyangkut kehidupan psikososial yang terjadi pada buruh migran. Berdasarkan pembacaan terhadap catatan harian Diary Buruh Migran, penulis melihat adanya permasalahan psikososial yang terjadi pada kaum proletar kelas buruh PRT TKW HK. Adapun fokus masalah dalam artikel ini secara spesifik meliputi (1) pandangan hidup tokoh setelah melewati pramigran dan migran dan (2) orientasi budaya tokoh setelah melewati pramigran dan migran. Masing-masing hasil analisis tokoh buruh migran dalam teks catatan harian Diary Buruh Migran karya Arsya Kirana tersebut, dijelaskan seperti di bawah ini.

\section{Pandangan Hidup Tokoh setelah Melewati Pramigran dan Migran}

Pandangan hidup tokoh yang dimaksud dalam penelitian ini adalah pedoman hidup buruh migran setelah melalui proses prefiguratif dan konfiguratif dalam pramigran dan migran. Pandangan hidup tokoh ini digunakan sebagai dasar untuk menentukan pemantaban identitas personal tokoh buruh migran. Melalui pandangan hidup tokoh, identitas baru tokoh buruh migran terbentuk, yaitu bagaimana tokoh buruh migran melihat dunia yang dihadapinya berdasarkan orientasi sosial dan kultural yang dipahaminya melalui proses pramigran dan migran. Tokoh buruh migran melalui proses ini dapat menentukan jati dirinya, sebab dia telah memiliki pemaknaan yang mendalam tentang dirinya, dari mana dia berpijak dan sikap dia dalam mengambil peran dalam kehidupan.

Pandangan hidup tokoh buruh migran setelah melalui proses pramigran dan migran yang terepresentasi dalam Diary Buruh migran karya Arsya Kirana ini meliputi dua hal, yakni: (1) Pedoman hidup buruh migran dalam menghadapi diskriminasi dan (2) Pedoman hidup buruh migran dalam memandang materi. Berikut hasil analisis untuk masing-masing pandangan hidup tokoh setelah melewati pramigran dan migran. 


\section{Pedoman Hidup Buruh Migran dalam Menghadapi Diskriminasi}

Diskriminasi yang dimaksud dalam penelitian ini adalah diskrimanasi profesi yang dialami oleh tokoh buruh migran. Secara sosial horizontal orang memandang profesi sebagai buruh migran adalah profesi rendah, tidak berkelas, dan dipandang sebelah mata. Sedangkan secara sosial vertikal buruh migran sering kali mendapatkan pelanggaran oleh majikan, baik pelanggaran fisik maupun psikologis.

Sebagaimana prefiguratif tokoh buruh migran, dalam ruang pengalamannya, buruh migran memiliki latar belakang yang menyedihkan. Latar belakang keluarga orang tua tunggal, keadaan ekonomi yang miskin, dan pendidikan rendah telah menunbuhkan tekad yang kuat pada diri buruh migran untuk bekerja keras menuai sukses di negeri orang dengan berprofesi sebagai buruh migran. Satu cita-cita yang menjadi keinginannya yaitu dapat mengubah kehidupannya menjadi lebih baik. Namun, dalam perjalannya tidak mudah dalam mewujudkan impian buruh migran. Sebagaimana dalam proses konfiguratif, banyak hambatan dan rintangan mulai dari proses pemberangkatan hingga berada di Hong Kong yang harus di lalui oleh buruh migran.

Buruh migran dalam menjalani keseharian profesinya banyak mendapatkan diskriminasi, terutama diskriminasi yang dilakukan oleh majikan di tempat dia bekerja. Diskriminasi profesi tersebut meliputi pelanggaran psikologi berupa cercaan dan makian yang hampir setiap hari harus diterima buruh migran. Namun, karena buruh migran sudah terbiasa hidup susah, dia menganggap apa yang selama ini dia rasakan belum apa-apa dengan penderitaan yang selama ini dia jalani. Buruh migran berpendapat bahwa diskriminasi yang dialami bukanlah harga mati dalam meniti hidup. Pengalaman buruk yang selama ini dialami buruh migran semakin mengukuhkan identitas personal buruh migran. Buruh migran menjadi sosok yang lebih sabar dan ikhlas dalam menghadapi persoalan dalam hidup. Sikap sabar dan ikhlas ini muncul setelah buruh migran melalui melalui pengalaman buruk dalam proses prefiguratif dan konfiguratif. Berikut data yang menunjukkan pedoman hidup buruh migran dalam menghadapi diskriminasi.

Hari kesekian aku bekerja. Aku masih saja bergelut dengan profesi buruh migran. Namun saat ini aku sudah merasa lelah. Kehidupan terasa membosankan. Sebaik-baiknya hidup bersama orang lain terkadang masih aku terima cercaan dan makian sebagai makanan harian. Diskriminasi dalam keseharian terkadang terasa meski kadarnya relatif. Berbagai pahit manis hidup di tanah rantau dengan profesi buruh migran ternyata bukan hal yang mudah, namun aku selalu berusaha untuk sabar dan ikhlas. Ini bukan harga mati dalam meniti hidup. (RPHHD 1) 
Selain menjadi pribadi yang sabar dan ikhlas, dalam refiguraif tokoh Eni menjadi pribadi yang pantang menyerah dan pandai bersyukur. Tokoh Eni, jika dalam prefiguratif keluarganya mengajarkan untuk hidup nrimo ing pandum, dalam perjalanan konfiguratifnya ada banyak hal yang harus memaksanya menjadi pribadi yang pantang menyerah. Citacitanya yang kuat untuk menggapai hidup berkecukupan secara materi, bemartabat dan memiliki masa depan cerah harus dijalaninya dengan usaha yang maksimal dan bekerja keras. Hal ini kemudian membentuk pribadi tokoh Eni menjadi figur yang pantang menyerah demi mendapatkan kehidupan yang lebih baik.

\section{Pedoman Hidup Buruh Migran dalam Memandang Materi}

Tokoh Eni dalam refigurasi memiliki kepribadian yang pandai bersyukur karena dia merasa banyak teman sesama buruh migran yang memiliki nasib yang lebih buruk daripada dirinya. Tokoh Eni hanya diam ketika mendapatkan pelanggaran psikologi dari majikannya, dia juga enggan menceritakan penderitaannya selama bekerja kepada keluarga karena hanya menambah beban keluarga. Satu-satunya jalan yang mampu membuatnya bertahan adalah dengan melihat ke bawah, banyak teman-teman sesama buruh migran yang memiliki permasalahan yang lebih berat darinya, sebagaimana dijelaskan dalam konfiguratif. Berikut data yang menunjukkan pedoman hidup buruh migran dalam menghadapi diskriminasi.

Sebagai manusia biasa, aku juga menginginkan hidup berkecukupan, bermartabat dan bermartabat cerah. Meski kehidupan buruh migran sulit, tidak pernah terbayangkan hidup berlehaleha. Jeda istirahat hanya untuk mempersiapkan kerja keesokan hari, menjaga tenaga agar tetap terkumpul jangan sampai sakit dan mempersetankan perasaan sendiri. Sebagai bagian buruh migran pantang menyerah dan berharap mendapatkan sesuatu yang lebih baik. (RPHHD 2)

Mulutku terkunci rapat. Hanya pilu yang kurasa saat amarah majikan membakar jiwa. Aku tidak ingin mengeluh karena justru menambah beban keluarga maupun bagiku sendiri. Aku tidak sendiri, masih banyak yang lebih parah dariku. Aku tidak boleh terus melihat ke atas, saatnya menengok ke bawah agar aku bisa selalu bersyukur atas apa yang aku alami. (RPHHD 3)

Buruh migran, hampir semuanya memiliki tekad yang sama, memiliki cita-cita yang sama, yaitu menginginkan kehidupan yang lebih baik secara materi karena dilandasi latar belakang keluarga yang miskin. Namun, pada kenyataannya menjadi buruh migran tidak ada bedanya dengan perbudakan. Aktivitas buruh migran merupakan perbudakan yang mengalami metamorfosa atau lebih tepatnya perbudakan modern. Tenaga buruh migran diperah habis-habisan dengan gaji yang hanya cukup digunakan untuk bertahan hidup. Menjadi buruh migran tidak semudah yang dibayangkan, bayangan materi berlimpah dengan 
gaya hidup glamour. Semuanya membutuhkan pengorbanan, belum permasalahan yang harus dihadapi oleh masing-masing buruh migran yang berbeda-beda.

Pengalaman demi pengalaman yang dilalui oleh tokoh Eni telah mengukuhkan identitas personal tokoh Eni. Bahwasanya keberhasilan seseorang tidak melulu tentang materi. Kesuksesan seseorang tidak selalu diukur dengan uang. Kesabaran yang menjadi kekayaan jiwa dan kesabaran hati ternyata lebih penting dari sekadar materi. Hidup ini memang membutuhkan uang, tapi tidak semua hal dalam kehidupan ini selalu bergantung pada uang. Kebahagiaan hidup adalah salah satu yang tidak dapat dibeli dengan uang. Ada sisi lain yang lebih utama dibanding dengan materi yang selama ini dicita-citakan buruh migran, yaitu (1) semangat pantang menyerah, (2) bersyukur, dan (3) kebahagiaan hidup. Berikut data yang menunjukkan pedoman hidup buruh migran dalam menyikapi hakikat kesuksesan dalam hidupnya.

Rasa bimbang dan ragu juga aku alami seperti halnya dulu ketika akan pergi ke negeri migran. Sudah cukup bagiku, meski secara kasat mata aku tak berlimpah materi. Aku mensyukuri dengan apa yang kudapat. Hanya rasa optimis yang kubawa pulang. Kesuksesan tak selalu diukur dengan materi, begitu juga diri ini. Cukuplah kesabaran yang menjadi kekayaan jiwa. (RPHHD 4)

Aktivitas sebagai buruh migran merupakan perbudakan yang mengalami metamorfosa. Buruh migran memang bukan milik majikan, namun tenaganya sama-sama terperas habis dengan penghasilan yang cukup untuk mempertahankan hidup. Aku telah terbiasa hidup dengan majikan yang tidak mendeskriminasikan manusia hingga betah bekerja bertahun-tahun. Bahkan sempat berpikir tak ingin kembali ke tanah air. Namun, tatkala terhadang kenyataan pahit, kurasakan diriku sebagai warga minoritas di negeri rantau. Rasanya ingin segera berlari. Semua hal yang aku jalani hanya keterpaksaan. Mau tidak mau, semua harus kuterima. (RPHHD 5)

Memang ada benarnya apa yang telah diungkapkan oleh Ratna. Semua alur kehidupan di sini seakan berjalan dengan uang. Tanpa uang tak ada yang bergerak. Benar juga bait lagu yang dinyanyikan Rhoma Irama, dari bayi hingga mati sekalipun butuh uang. Tapi apakah hidup hanya untuk uang selamanya? Sehingga kita menjadi manusia yang diperbudak oleh uang? Iya, uang memang penting. Hidup seakan hanya untuk uang sehingga hidup terkendali oleh uang. Memang hidup butuh uang, tapi semua hal dalam kehidupan ini tidak selalu bergantung pada uang. Ada yang tak bisa dibeli dengan uang, seperti kebahagiaan hati. (RPHHD 6)

\section{Orientasi Ideologi Tokoh setelah Melewati Pramigran dan Migran}

Buruh migran sebagai warga negara yang memiliki latar belakang miskin, berpendidikan rendah, dan latar belakang keluarga yang kurang harmonis tentu tidak akan pernah berpikir tentang arti nasionalisme. Hal ini disebabkan karena jangankan untuk memikirkan nasionalisme, berpikir bagaimana cara bertahan hidup saja sudah susah. Sehingga rasa nasionalisme ini tidak muncul pada buruh migran sebelum mereka melakukan migrasi. Baru setelah mereka melakukan migrasi, dan bergaul pada kancah internasional, maka nasionalisme mereka terpupuk. Nasionalisme buruh migran ini muncul karena mereka 
merasakan bagaimana menjadi orang minoritas di negeri orang. Bagaimana bangsa lain memiliki perspektif bahwa orang Indonesia itu bodoh, yang kemudian memunculkan keinginan kuat bahwa apa yang bangsa lain tuduhkan itu tidak benar.

Hong Kong adalah negara modern dengan fasilitas yang serba canggih. Tentu saja hal ini membawa pengaruh budaya tersendiri terhadap buruh migran yang sedang mengais rejeki di sana. Budaya materialistik, konsumerisme, hedonisme adalah budaya asing yang mengancam pola pikir buruh migran. Sebagian besar buruh migran dalam proses konfiguratif banyak yang larut dalam budaya tersebut. Namun dalam refiguratif, pada akhirnya buruh migran menyadari bahwa bangsa Indonesia harus memiliki jiwa karakter nasionalisme. Harus menjadi bangsa yang tidak malu mengakui budaya Indonesia, dan bangga mengakui sebagai bangsa Indonesia. Pada akhirnya buruh migran menemukan jati dirinya bahwa dalam orientasi budaya, mereka memiliki pandangan semodern apapun negara tempat berpijak mereka tetap memegang garis-garis budaya Indonesia. Kemanapun buruh migran melangkah, ke Indonesia mereka kembali. Hal ini semakin mengukuhkan identitas personal buruh migran sebagai orang Indonesia yang memiliki tumpah darah Indonesia dan hidup mati tetap sebagai orang Indonesia.

Tempat berpijak terkadang tak selalu mempengaruhi pola pikir. Semodern apapun masih terlihat garis-garis budaya Indonesia asli. Dari hal itulah bisa disimpulkan meski bangga dengan tempat berpijak, masih ingat tentang tempat yang membesarkannya. Tak perlu malu mengakui Indonesia sebagai negara asal. Aku, Ratna, atau mereka masih tetap orang Indonesia. Ke manapun aku melangkah di penjuru bumi, pasti di Indonesia kukembali. Darahku adalah darah orang Indonesia, hidup mati tetap Indonesia. (ROB 1)

Pergolakan hidup buruh migran dalam proses prefiguratif dan konfiguratif telah mengukuhkan identitas personal buruh migran dalam orientasi ideologi yang menjadi pedoman hidupnya. Buruh migran menjadi pribadi yang sadar akan nasionalisme dalam kancah pergaulan internasionalnya, dan bangga akan identitas budaya Indonesia asli yang dimilikinya. Selain itu, kebanggaan menjadi bangsa Indonesia oleh buruh migran direpresentasikan dengan pengakuan atas tumpah darah Indonesia yang diwujudkan dengan hidup mati tetap menjadi orang Indonesia.

\section{SIMPULAN DAN SARAN}

\section{Simpulan}

Refigurasi sebagaimana wilayah pemahaman akhir terhadap makna hidup tokoh yang telah dilewati semenjak alur prefiguratif dalam ruang pengalaman dan konfiguratif dalam ruang pengharapan PRT TKW HK. Berdasarkan hasil penelitian ini dapat disimpulkan bahwa 
setelah melalui proses prefiguratif dan konfiguratif ternyata buruh migran memiliki orientasi ideologi yang berbeda dari cita-cita buruh migran semula. Buruh migran tidak konsisten dengan apa yang dicita-citakan karena beberapa hal yang terjadi dalam proses konfiguratif. Materi bukanlah tujuan hidup buruh migran, kesuksesan tidak selalu diukur dengan uang dan cukup kesabaran yang menjadi kekayaan jiwa dan kebahagiaan hidup. Buruh migran sadar bahwa ada sesuatu yang tidak dapat dibeli dengan uang, yaitu ketenangan jiwa.

\section{Saran}

Pemerintah hendaknya memberikan pembiayaan yang murah terhadap pendidikan, mengingat sebagian besar PRT TKW HK memiliki pendidikan rendah yang mengakibatkan berbagai masalah di negara tujuan. Selain itu, penting untuk memperluas lapangan kerja di dalam negeri sehingga warga negara Indonesia tidak perlu menjadi PRT TKW HK.

Lembaga pendidikan diharapkan dapat mengembangkan karya sastra buruh migran sebagai bahan perkuliahan. Apresiasi terhadap hasil karya sastra buruh migran secara teknis dapat dilakukan dengan mengarahkan dan memberikan tugas kepada mahasiswa untuk meneliti dan menelaah karya sastra buruh migran. 


\section{DAFTAR RUJUKAN}

Adidharta, Syafud. 2011. Kebebasan Hongkong Surganya Para TKI/TKW. Kompasiana, (Online), (http://m.kompasiana.com, diakses 21 November 2016)

Afifah, Nadiya. 2015. Peran Pemerintah Indonesia dalam Mengatasi Perilaku Lesbian Tenaga Kerja Wanita di Hongkong. Portal Garuda, (Online), (http://portalgaruda.org, diakses 21 November 2016).

Ardiansyah, Syamsul. 2008. Hukum Agency yang Menahan Paspor dan Kontrak Kerja BMI. Asosiasi Tenaga Kerja Indonesia Hongkong, (Online), (http://atkihongkong.blogspot.co.id, diakses 21 November 2016).

Endraswara, Suwardi. 2013. Metodologi Penelitian Sastra Epistimologi, Model, Teori, dan Aplikasi. Yogyakarta: CAPS (Center for Academic Publishing Service).

Fatihuddin. 2013. Waspadai Gerakan Pemurtadan Sedang Mengintai Kita. Majalah Peduli Umat, (Online), (http://majalahpeduliumat.blogspot.co.id, diakses 21 November 2016).

Husna, Aftina N. 2015. Orientasi Hidup Materialistik dan Kesejahteraan Psikologis. Seminar Psikologi \& Kemanusiaan, hlm. 7-13.

Indarti, Titik dan Subandiyah, Heny. 2007. Representasi Perempuan dalam Sastra Buruh Migran di Hongkong Asal Indonesia. Penelitian tidak diterbitkan. Jakarta: Pusat Dokumentasi dan Informasi Ilmiah-Lembaga Ilmu Pengetahuan Indonesia PDII-LIPI.

Indarti, Titik. 2016. Gerakan Sastra Perempuan Buruh Migran Indonesia di Hongkong. Disertasi tidak diterbitkan. Malang: Program Pascasarjana Universitas Negeri Malang.

Kamalia, Naila. 2013. Karakteristik tokoh dan penokohan dalam cerpen karya buruh migran Indonesia Hongkong. Skripsi tidak diterbitkan. Malang: Fakultas Sastra Universitas Negeri Malang.

Kirana, Arsya. 2014. Diary Buruh Migran. Yogyakarta: Revive.

Moleong, Lexy J. 2010. Metode Penelitian Kualitatif. Bandung: Rosda.

Nurkhoiron, Muhammad \& Ujianto, Ari (Eds.). 2010. Identitas Perempuan Indonesia, Status, Pergeseran Relasi Gender, dan Perjuangan Ekonomi Politik. Depok: Desantara Foundation.

Robbins, Stephen P. 1996. Perilaku Organisasi. Jakarta: Prenhallindo.

Samani, Muchlas dan Hariyanto. 2014. Pendidikan Karakter. Bandung: Remaja Rosdakarya Offset.

Saryono, Djoko. 2008. Perempuan dalam Fiksi Indonesia: Sang Tokoh dan Sang Pengarang. Malang: Pustaka Kayutangan. 
Sasongko, Agung. 2015. Fenomena Lesbi Kian Marak di Kalangan TKW Hongkong. Republika, (Online), (http://m.republka.co.id, diakses 21 November 2016).

Sawai, Shiho. 2008. "Potensi Teleopoiesis dan Marginalitas Berlipat dalam Karya Buruh Migran Perempuan di Hong Kong”, dalam Jurnal Cerpen Indonesia, Edisi 09/2008, hlm. 149-172.

Stoner, James A.F. dan Freeman, F. 1989. Personal Management. New Jersey: Prentice-Hall inc.

Sugiono, Yudi. 2015. Perjuangan Para Pahlawan Devisa. Kompasiana, (Online), (http://m.kompasiana.com, diakses 21 November 2016)

Sumardjo, Jakob dan Saini K.M. 1986. Apresiasi Kesusastraan. Jakarta: Gramedia.

Susanti, Nana Riskhi. Tanpa tahun. Diplomasi Perempuan Victoria Park. (Online). (http://unnes.ac.id, diakses 12 November 2015).

Taum, Yoseph Yapi.1977. Pengantar Teori Sastra. Flores: Nusa Indah.

Umar, Risma. 2010. Menguak Pelanggaran Hak Asasi Buruh Migran IndonesiaCatatan Penanganan Kasus Buruh Migran Perempuan-Pekerja RumahTangga (BMP-PRT) Solidaritas Perempuan Tahun 2005-2009 (Ed.). Jakarta Selatan: Solidaritas Perempuan.

Winardi. 1992. Management Perilaku Organisasi. Bandung: Citra Aditya Bakti.

Vemena, Henry I. 1996. Paul Recoeur's Interpretation of Selfhood and its significance for Philosophy of Religion. Tesis tidak diterbitkan. Montreal: Faculty of R eligious Studies McGill University. 